\title{
PENERAPAN MODEL PEMBELAJARAN KOOPERATIF GIVING QUESTION AND GETTING ANSWER TERHADAP AKTIVITAS BELAJAR DAN HASIL BELAJAR SISWA PADA MATERI MENERAPKAN PROSEDUR KEGIATAN RAPAT
}

\author{
Rosmarintan Sihombing \\ Sekolah Menengah Kejuruan Negeri 1 Sidikalang \\ sihombingrosmarintan@gmail.com
}

\begin{abstract}
Abstrak: Tujuan penelitian ini adalah untuk mengetahui peningkatan hasil belajar siswa pada mata pelajaran produktif OTKP materi menerapkan prosedur kegiatan rapat di kelas XI OTKP 2 SMK Negeri 1 Sidikalang. Melalui penerapan model pembelajaran kooperatif Giving Question anda Getting Answer. Model pembelajaran kooperatif Giving Question and Getting Answer merupakan salah satu strategi pembelajaran aktif. Penelitian ini dilaksanakan di SMK Negeri 1 Sidikalang pada siswa Kelas XI OTKP Semester II T.P. 2018/2019 yang berjumlah 36 orang. Hasil penelitian diperoleh: (1) Penerapan model pembelajaran kooperatif Giving Question and Getting Answer dapat meningkatkan aktivitas belajar siswa. Hasil obsevasi siklus I diperoleh data bahwa terdapat 30 orang (83,33\%) siswa untuk kriteria cukup aktif, dan 6 orang $(16,66 \%)$ siswa yang aktif. Sementara pada siklus II peningkatan data hasil obsevasi aktivitas siswa menunjukkan 6 orang (16,66\%) siswa untuk kriteria cukup aktif, 27 orang (75\%) siswa untuk kriteria aktif, dan 3 orang (8,33\%) siswa untuk kriteria sangat aktif. (2) Model pembelajaran kooperatif Giving Question and Getting Answer dapat meningkatkan hasil belajar siswa. Pada siklus I diperoleh nilai rata-rata 70,27 dan persentase ketuntasan belajar siswa sebesar $36,11 \%$ selanjutnya pada siklus II diperoleh nilai rata-rata 81,38 dan persentase ketuntasan siswa sebesar $88,88 \%$ dari jumlah siswa yang telah mencapai standar kriteria ketuntasan minimal.
\end{abstract}

Kata Kunci: model pembelajaran, kooperatif giving question, getting answer, aktivitas belajar, hasil belajar, menerapkan prosedur kegiatan rapat.

\begin{abstract}
The purpose of this study was to determine the increase in student learning outcomes in productive subjects OTKP material to implement the procedure of meeting activities in class XI OTKP 2 Vocational High School 1 Sidikalang. Through the application of your Giving Question cooperative learning model Getting Answer. The Giving Question and Getting Answer cooperative learning model is one of the active learning strategies. This research was conducted at Vocational High School 1 Sidikalang on Class XI students of OTKP Semester II T.P. 2018/2019 of 36 people. The results are obtained: (1) The application of the Giving Question and Getting Answer cooperative learning model can improve student learning activities. The results of observing the first cycle obtained data that there were 30 people $(83.33 \%)$ students for the criteria of being quite active, and 6 people (16.66\%) students who were active. While in the second cycle the increase in data on the results of observations of student activity showed 6 people (16.66\%) students for the moderately active criteria, 27 people (75\%) students for the active criteria, and 3 people (8.33\%) students for the very active criteria. (2) The Giving Question and Getting Answer cooperative learning model can improve student learning outcomes. In the first cycle obtained an average value of 70.27 and the percentage of students learning completeness of $36.11 \%$ then in the second cycle obtained an average value of 81.38 and the percentage of students completeness of $88.88 \%$ of the number of students who have reached the criteria standard minimal completeness.
\end{abstract}

Keywords: learning models, cooperative giving questions, getting answers, learning activities, learning outcomes, implementing meeting activities procedures.

\section{PENDAHULUAN}

Tujuan pendidikan adalah adanya perubahan perilaku yang diinginkan terjadi setelah siswa belajar. Pendidikan yang diperoleh seseorang amat penting karena akan membangkitkan motivasi yang lebih baik pada segala aspek kehidupan. Oleh karena itu, pendidikan merupakan usaha sadar untuk menyiapkan peserta didik melalui kegiatan bimbingan, pengajaran dan atau latihan dan peranannya dimasa yang akan datang (Nursalim, 2007:2).

Guru memegang peranan penting dalam keberhasilan siswanya, sebaik apapun kurikulum yang disajikan, sarana dan prasarana terpenuhi, tetapi apabila guru kurang berkualitas maka proses belajar mengajar belum dikatakan baik. Seorang guru yang ideal akan 
mampu bertindak kritis dalam menjalankan tugasnya secara profesional dan dapat menentukan alternatif yang harus diambil dalam proses belajar mengajar guna tercapainya tujuan pembelajaran itu sendiri.

Dalam penelitian ini, peneliti menggunakan model pembelajaran kooperatif Giving Question and Getting Answer, dimana model pembelajaran ini merupakan salah satu upaya yang dapat dilakukan agar hasil belajar siswa lebih baik. Model pembelajaran kooperatif Giving Question and Getting Answer adalah suatu model pembelajaran yang dikembangkan untuk melatih siswa memiliki kemampuan bertanya dan menjawab pertanyaan. Berdasarkan uraian di atas, maka saya tertarik untuk mengadakan penelitian dengan judul "Penerapan Model Pembelajaran Kooperatif Giving Question and Getting Answer Terhadap Aktivitas Belajar dan Hasil Belajar Siswa Pada Materi Menerapkan Prosedur Kegiatan Rapat di Kelas XI OTKP 2 SMK Negeri 1 Sidikalang Tahun Pelajaran 2018/2019".

\section{Pembelajaran Kooperatif Giving Question and Getting Answer}

Model pembelajaran adalah suatu perencanaan atau suatu pola yang digunakan sebagai pedoman bagi perancang pembelajaran dalam merencanakan pembelajaran di kelas atau pembelajaran dalam tutorial. Fungsi model pembelajaran disini adalah sebagai pedoman bagi perancang pengajar dan para guru dalam melaksanakan pembelajaran.

Menurut Trianto (2010: 51) model pembelajaran adalah suatu perencanaan atau suatu pola yang digunakan sebagai pedoman dalam merencanakan pembelajaran di kelas. Model pembelajaran mengacu pada pendekatan pembelajaran yang akan digunakan, termasuk di dalamnya tujuan-tujuan pengajaran, tahap-tahap dalam kegiatan pembelajaran, lingkungan pembelajaran dan pengelolaan kelas". Berdasarkan pendapat di atas, maka dapat disimpulkan bahwa model pembelajaran adalah suatu perencanaan dalam mengorganisasikan belajar dalam mencapai tujuan pembelajaran tertentu.

Menurut Isjoni (2011: 14) menyatakan bahwa: Pembelajaran kooperatif merupakan strategi belajar dengan sejumlah peserta didik sebagai anggota kelompok kecil yang tingkat kemampuannya berbeda dalam menyelesaikan tugas kelompoknya, setiap anggota kelompok harus saling bekerja sama dan saling membantu untuk memahami materi pelajaran. Dan belajar dikatakan belum selesai jika masih terdapat anggota kelompok yang belum menguasai bahan pelajaran.

Tujuan pembelajaran kooperatif berbeda dengan kelompok tradisional yang menerapkan sistem kompetisi, dimana keberhasilan individu diorientasikan pada kegagalan orang lain. Sedangkan tujuan dari pembelajaran kooperatif adalah menciptakan situasi dimana keberhasilan individu ditentukan atau dipengaruhi oleh keberhasilan kelompoknya.

Asmawati, dkk (2011: 91) mengatakan bahwa sesuai dengan tujuan penerapan model pembelajaran kooperatif tipe Giving Question and Getting Answer yaitu mengecek pemahaman para siswa sebagai dasar perbaikan proses belajar mengajar, membimbing para siswa untuk memperoleh suatu keterampilan kognitif maupun sosial serta memberikan rasa senang pada siswa. Memotivasi siswa agar terlibat dalam interaksi, melatih kemampuan mengutarakan pendapat, dan mencapai tujuan belajar. Kegiatan bertanya dan menjawab yang dilakukan oleh siswa mampu menumbuhkan pengetahuan baru pada diri siswa.

Amalia Chasanah, dkk (2012:30) mengatakan bahwa strategi pembelajaran Giving Question and Getting Answer (GQGA) merupakan salah satu strategi pembelajaran Active Learning yang mengimplementasikan dari strategi pembelajaran konstruktivistik yang menempatkan siswa sebagai subjek dalam pembelajaran yang dikembangkan untuk melatih siswa memiliki kemampuan dan keterampilan bertanya dan menjawab karena pada dasarnya model tersebut merupakan modifikasi dari tanya jawab.

Penelitian yang dilakukan Muktiani (2012) dalam penelitian yang berjudul "Penerapan Metode Pembelajaran Giving Question and Getting Answer untuk Meningkatkan Keaktifan dan Hasil Belajar Akuntansi Pada Siswa. Hasil penelitian ini menunjukkan adanya peningkatan keaktifan dan hasil belajar akuntansi siswa. Hasil penelitian ini menunjukkan bahwa sebelum tindakan diperoleh rata-rata tingkat keaktifan mencapai $18,92 \%$ dan hasil belajar akuntansi yang mencapai KKM 45,95 \% dengan nilai rata-rata 64,33. Pada siklus I tingkat keaktifan siswa meningkat menjadi 42,08\% dan hasil belajar yang mencapai KKM sebanyak 62,17\% dengan 
nilai hasil belajar siswa 74,84. Pada siklus II tingkat keaktifan siswa rata-rata meningkat menjadi $72,2 \%$ dan hasil belajar siswa yang mencapai KKM sebanyak 75,68 \% dengan nilai hasil belajar siswa 77,25. Berdasarkan data hasil penelitian tindakan kelas tersebut maka dapat disimpulkan bahwa dengan menerapkan metode Giving Question and Getting Answer dapat meningkatkan keaktifan dan hasil belajar akuntansi pada siswa.

Penelitian yang dilakukan oleh Veranita (2010) dalam Penerapan Strategi Pembelajaran Aktif tipe Giving Question and Getting Answer Untuk Meningkatkan Aktivitas Siswa Dalam Pembelajaran Matematika. Hasil penelitian ini menunjukkan adanya peningkatan aktivitas siswa dalam pembelajaran matematika pada pokok bahasan himpunan melalui strategi pembelajaran aktif tipe Giving Question and Getting Answer. Hal ini dapat dilihat dari aktivitas siswa sebelum diadakan tindakan sebesar $27,62 \%$ dan di akhir tindakan mencapai $47,18 \%$. Hasil tes tertulis yang dilakukan sebelum dan sesudah penelitian menunjukkan adanya peningkatan pada prestasi belajar siswa. Sebelum adanya tindakan prestasi belajar siswa yang mencapai instrument ketuntasan minimal (KKM) sebesar 73,81\% dan di akhir tindakan mencapai 84,62 . Penelitian ini menyimpulkan bahwa penerapan strategi pembelajaran aktif tipe Giving Question and Getting Answer dalam pembelajaran matematika pada pokok bahasan himpunan dapat meningkatkan aktiviiitas siswa sehingga berdampak pada prestasi siswa.

Penelitian yang dilakukan oleh Susanti Nelya Eka (2012) tentang Penerapan Model Pembelajaran Kooperatif Giving Question and Getting Answer untuk meningkatkan aktivitas dan hasil belajar IPS Geografi diketahui bahwa aktivitas belajar siswa tergolong masih rendah, hal ini dapat dilihat pada saat pembelajaran berlangsung. Siswa cenderung pasif atau aktif dengan kegiatannya sendiri seperti mengganggu teman di sebelahnya disaat guru menyampaikan materi, siswa kelas VII-H ini cenderung susah untuk diajak fokus pada pembelajaran. Selain itu diperoleh data bahwa hasil belajar UTS IPS siswa pada materi sebelumnya tergolong masih rendah, karena hanya 39,1\% dari 23 siswa yang memiliki nilai 70 . Untuk itu perlu diterapkannya model pembelajaran inovatif yang dapat melibatkan siswa secara aktif sehingga dapat berdampak positif terhadap hasil belajar siswa.

Berdasarkan pendapat di atas dapat disimpulkan bahwa Giving Question and Getting Answer merupakan cara pembelajaran yang menuntut siswa untuk bekerja sama dan dapat meningkatkan rasa tanggung jawab atas apa yang telah dipelajari. Setiap siswa diberikan kesempatan untuk bertanya mengenai hal yang tidak dimengerti kepada temannya yang lain. Adapun langkah-langkah tersebut adalah sebagai berikut :

Tabel 1. Langkah-langkah Pembelajaran Kooperatif

\begin{tabular}{|c|l|l|}
\hline No & \multicolumn{1}{|c|}{ Fase-fase } & \multicolumn{1}{c|}{ Perilaku Guru } \\
\hline 1 & $\begin{array}{l}\text { Menyampaikan tujuan dan } \\
\text { mempersiapkan peserta } \\
\text { didik }\end{array}$ & $\begin{array}{l}\text { Guru menjelaskan tujuan pembelajaran dan mempersiapkan } \\
\text { peserta didik siap belajar }\end{array}$ \\
\hline 2 & Menyajikan informasi & $\begin{array}{l}\text { Mempresentasikan informasi kepada peserta didik secara } \\
\text { verbal }\end{array}$ \\
\hline 3 & $\begin{array}{l}\text { Mengorganisir peserta } \\
\text { didik ke dalam tim-tim } \\
\text { belajar atau kelompok } \\
\text { diskusi }\end{array}$ & $\begin{array}{l}\text { Memberikan penjelasan kepada peserta didik tentang cara } \\
\text { pembentukan tim belajar dan membantu kelompok melakukan } \\
\text { transisi yang efisien }\end{array}$ \\
\hline 4 & Membantu tim dan belajar & $\begin{array}{l}\text { Membantu tim-tim belajar selama peserta didik mengerjakan } \\
\text { tugas }\end{array}$ \\
\hline 5 & Mengevaluasi & $\begin{array}{l}\text { Menguji pengetahuan peserta didik mengenai berbagai materi } \\
\text { pembelajaran atau kelompok-kelompok mempresentasikan } \\
\text { hasil kerja }\end{array}$ \\
\hline 6 & $\begin{array}{l}\text { Memberikan penghargaan } \\
\text { atau pengakuan }\end{array}$ & $\begin{array}{l}\text { Mempersiapkan cara untuk mengakui usaha dan presentasi } \\
\text { individu maupun kelompok }\end{array}$ \\
\hline
\end{tabular}

Sumber : Ibrahim (dalam Trianto, 2010:67) 


\section{Hasil Belajar}

Belajar merupakan proses dalam diri individu yang berinteraksi dengan lingkungan untuk mendapatkan perubahan dalam perilakunya. Menurut Gagne (dalam Sagala, 2012: 13) bahwa "belajar adalah sebagai suatu proses dimana suatu organisma berubah perilakunya sebagai akibat dari pengalaman".

Menurut Djamarah (2010: 10) "Belajar adalah proses perubahan perilaku berkat pengalaman dan latihan. Artinya, tujuan kegiatan adalah perubahan tingkah laku, baik yang menyangkut pengetahuan, ketrampilan maupun sikap, bahkan meliputi segenap aspek organisme atau pribadi”.

Dari beberapa pendapat tersebut, dapat disimpulkan bahwa pengertian belajar secara umum adalah suatu proses usaha yang dilakukan seseorang untuk memperoleh suatu perubahan tingkah laku yang baru secara keseluruhan sebagai hasil pengalamannya sendiri dalam interaksi dengan lingkungannya.

Elly Nor Indah (2014: 56) mengatakan bahwa hasil belajar adalah kemampuan yang diperoleh anak setelah melalui kegiatan belajar berupa tercapainya tujuan-tujuan pembelajaran dan pencapaian perubahan perilaku yang cenderung menetap untuk domain ranah kognitif, afektif dan psikomotor.

Hartati (2012: 2) menyatakan bahwa hasil belajar yang maksimal dapat diupayakan melalui faktor-faktor yang mempengaruhinya. Setiap kegiatan evaluasi pembelajaran harus memperhatikan faktor isi pembelajaran dan proses pembelajaran.

Berdasarkan pengertian hasil belajar di atas maka dapat disimpulkan bahwa hasil belajar adalah suatu penilaian akhir dari proses belajar dan pengenalan yang telah dilakukan dalam membentuk pribadi individu yang selalu ingin mencapai hasil yang lebih baik lagi sehingga akan merubah tingkah laku yang berupa kognitif, afektif, dan psikomotorik yang diperoleh peserta didik setelah mengikuti kegiatan belajar mengajar.

\section{Aktivitas Belajar Siswa}

Aktivitas siswa sangat diperlukan dalam kegiatan belajar mengajar sehingga siswalah yang seharusnya banyak aktif, sebab siswa sebagai subjek didik adalah merencanakan dan ia sendiri yang melaksanakan belajar. Aktivitas adalah segala jenis kegiatan yang dilakukan oleh siswa dalam belajar dengan tujuan perubahan tingkah laku, baik menyangkut pengetahuan, keterampilan maupun sikap, baik meliputi aspek organisme maupun pribadi.

Menurut Kunandar (2008: 277) "Aktivitas belajar adalah keterlibatan siswa dalam bentuk sikap, pikiran, perhatian, dan aktivitas dalam kegiatan pelajaran guna menunjang keberhasilan proses belajar dan memperoleh manfaat dari kegiatan tersebut". Berdasarkan pendapat tersebut dapat disimpulkan bahwa aktivitas belajar akuntansi adalah suatu kegiatan yang dilakukan siswa untuk memperoleh perubahan tingkah laku, pengetahuan, keterampilan dalam usaha mengembangkan dirinya untuk lebih maju sehingga memperoleh manfaat dari kegiatan yang dilakukan. Aktivitas belajar siswa yang dimaksud disini adalah aktivitas jasmaniah maupun aktivitas mental.

Usman (2002:22) mengemukakan "Aktivitas belajar siswa dapat digolongkan ke dalam beberapa hal sebagai berikut: (1) Aktivitas visual (visual activities) seperti membaca, menulis, melakukan eksperimen dan demonstrasi (2) Aktivitas lisan (oral activities) seperti bercerita, membaca sajak, tanya jawab, diskusi, dan menyanyi; (3) Aktivitas mendengarkan (listening activities) seperti mendengarkan penjelasan guru, ceramah dan pengarahan; (4) Aktivitas gerak (motor activities) seperti senam, atletik, menari dan melukis; (5) Aktivitas menulis (writing activities) seperti mengarang, membuat makalah, dan membuat surat.

Dari beberapa pendapat di atas dapat disimpulkan bahwa aktivitas belajar adalah keterlibatan siswa dalam bentuk penglihatan, lisan, pendengaran, gerak dan menulis dalam kegiatan pembelajaran guna menunjang keberhasilan proses belajar mengajar dan memperoleh manfaat dari kegiatan tersebut.

\section{Prosedur Kegiatan Rapat}

Rapat (conference atau meeting) merupakan alat/media komunikasi kelompok yang bersifat tatap muka dan sangat penting, diselenggarakan oleh banyak organisasi, baik swasta maupun pemerintah untuk mendapatkan mufakat melalui musyawarah untuk pengambilan keputusan. Rapat juga dapat dijadikan sebagai media untuk berkomunikasi antar manusia atau pimpinan kantor dengan stafnya. Rapat adalah pertemuan antar anggota di lingkungan kantor/organisasi sendiri untuk membicarakan, merundingkan suatu masalah 
yang menyangkut kepentingan bersama Rapat adalah pertemuan para anggota organisasi/para pegawai untuk membahas hal-hal yang berhubungan dengan kepentingan organisasi.

Kegunan atau fungsi rapat, yaitu sebagai berikut: (1) Forum diskusi untuk memecahkan masalah. (2) Forum silaturahmi. (3) Sarana bernegosiasi. (4) Ketetuan hukum. (5) Forum demokrasi : dengar pendapat dan meminta pertanggung jawaban. Brainstorming-sumbang saran. (7) Sarana berkonsultasi.

Harimanto dan Indrojiono berpendapat bahwa secara garis besar tujuan rapat adalah sebagai berikut : (1) Menyampaikan satu atau beberapa informasi, hal ini dilakukan dengan maksud jika penyampaian informasi tidak dilakukan secara langsung melalui rapat, maka dikhwatirkan akan menimbulkan salah persepsi bagi pegawai atau karyawannya. (2) Melibatkan beberapa orang yang memiliki kemampuan tertentu untuk memecahkan masalah yang dihadapi, sehingga masalah diharapkan dapat segera diatasi. (3) Menjalin kerja sama di antara anggota untuk membentuk suatu sikap yang diinginkan, karena jika tidak diadakan rapat maka kemungkinan anggota hanya akan memikirkan bagian pekerjaannya sendiri dan tidak memikirkan bagian lainnya. (4) Menyampaikan masalah, keadaan tertentu, complain, dan lain-lain yang tidak bisa dilakukan secara terbuka selain melalui rapat. (5) Memberi motivasi dan semangat kerja kepada para anggotanya melalui rapat.

Rapat bertujuan untuk mengambil keputusan sesuai dengan kewenangannya dari orang orang yang teribat di dalamnya.

Belajar menimbulkan perubahan perilaku. Dalam proses belajar akan menyebabkan perubahan pada siswa yaitu suatu keadaan yang lebih baik menuju tingkat keberhasilan siswa yang dicapai selama waktu tertentu. Dalam proses belajar mengajar di kelas, pembelajaran sering berlangsung satu arah atau hanya berpusat pada guru dalam arti guru kurang melibatkan siswa dalam pembelajaran. Dengan kata lain siswa kurang diberi kesempatan untuk berkembang dan mandiri melalui proses berpikirnya sehingga membuat siswa sering bosan, kurang berminat dan sulit memahami materi yang diajarkan oleh guru.

Model pembelajaran Giving Question and Getting Answers ini dikembangkan untuk melatih siswa memiliki kemampuan dan keterampilan bertanya dan menjawab pertanyaan. Pada dasarnya model tersebut merupakan modifikasi dan metode tanya jawab yang merupakan kolaborasi dengan menggunakan potongan-potongan kertas sebagai medianya. Dimana Giving Question and Getting Answer merupakan cara pembelajaran yang menuntut siswa untuk bekerja sama dan dapat meningkatkan rasa tanggung jawab atas apa yang telah dipelajari. Setiap siswa diberikan kesempatan untuk bertanya mengenai hal yang tidak dimengerti kepada temannya yang lain.

Guru memiliki peranan dalam mempengaruhi keaktifan belajar siswa. Dengan menerapkan model pembelajaran Giving Question and Getting Answers dalam kegiatan pembelajaran guru dituntut utuk dapat mengelola kelas secara aktif sehingga siswa dapat lebih tanggap dan paham terhadap materi pelajaran yang akan disajikan. Dengan adanya aktivitas yang baik diharapkan dapat meningkatkan hasil belajar siswa.

Rumusan masalah penelitian ini adalah bagaimana peningkatan hasil belajar siswa dengan penerapan model pembelajaran kooperatif Giving Question and Getting Answer pada mata pelajaran produktif OTKP materi menerapkan prosedur kegiatan rapat di kelas XI OTKP 2 SMK Negeri 1 Sidikalang.

\section{METODOLOGI PENELITIAN}

Penelitian dilaksanakan di SMK Negeri 1 Sidikalang yang beralamat di Jalan Ahmad Yani No. 136 A Batang Beruh Sidikalang. Subjek penelitian ini adalah siswa kelas XI OTKP 2 SMK Negeri 1 Sidikalang Tahun Pelajaran 2018/2019 yang berjumlah 36 orang. Yang menjadi objek penelitian ini adalah penerapan model pembelajaran kooperatif Giving Question and Getting Answer untuk meningkatkan aktivitas dan basil belajar mengelola pertemuan/rapat siswa.

\section{Defenisi Operasional}

Adapun yang menjadi defenisi operasional dalam penelitian ini adalah sebagai berikut : (1) Model pembelajaran kooperatif Giving Question and Getting Answer merupakan implementasi dari strategi pembelajaran konstrukstivistik yang menempatkan siswa sebagai subyek dalam pembelajaran. Artinya, siswa mampu merenkonstruksi pengetahuannya sendiri sedangkan guru hanya sebagai fasilitator saja. 
(2) Aktivitas siswa adalah kegiatan-kegiatan yang dilakukan siswa dalam proses belajar mengajar dengan menggunakan penerapan model pembelajaran kooperatif Giving Question and Getting Answer seperti keterlibatan siswa dalam bentuk sikap, pikiran, perhatian, dan aktivitas dalam kegiatan pembelajaran. (3) Hasil belajar siswa adalah suatu penilaian akhir dari proses belajar sehingga akan merubah tingkah laku yang berupa kognitif, afektif, dan psikomotorik yang diperoleh peserta didik setelah mengikuti kegiatan belajar mengajar.

\section{Prosedur Penelitian}

Jenis penelitian ini adalah peneiitian tindakan kelas (PTK). Secara umum desain pembelajaran menurut langkah-langkah penelitian tindakan kelas dilakukan dalam beberapa siklus dan informasi dari siklus terdahulu sangat menentukan siklus berikutnya. Penelitian tindakan kelas (classroom action research), meliputi 4 tahapan tiap siklusnya sebagai berikut:

a. Perencanaan tindakan

b. Pelaksanaan tindakan,

c. Ovservasi

d. Refleksi dan Evaluasi

(Arikunto dkk, 2009:16)

Berikut ini adalah bagan model penelitan tindakan kelas:

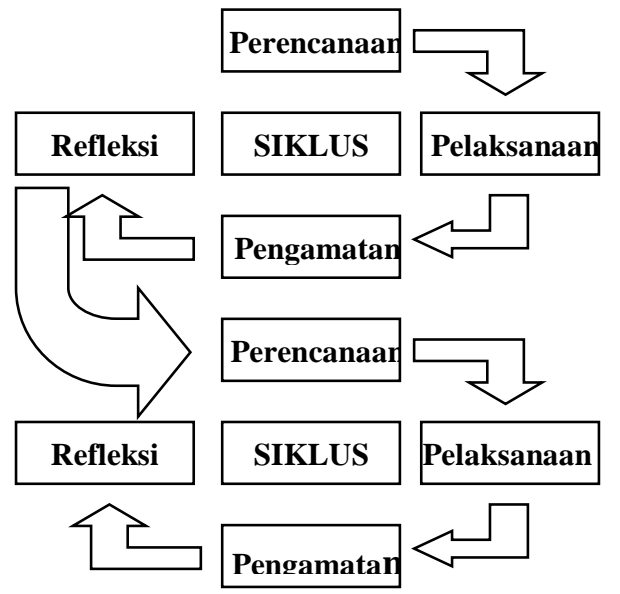

Gambar1. Siklus Model Kemmis dan Mc Taggart

Langkah-langkah operasional dalam prosedur penelitian di atas adalah:

a. Perencanaan (Planning): (1) Menganalisis kurikulum jurusan Otomatisasi dan Tata Kelola Perkantoran dan menentukan pokok bahasan yang akan dipelajari. (2)Menentukan dan mempersiapkan sumber- sumber pembelajaran yang akan digunakan, seperti buku, instrument dan referensi. (3)Mempersiapkan media yang akan digunakan dalam pembelajaran. (4)Mempersiapkan perangkat pembelajarann berupa silabus dan Rencana Pelaksanaan Pembelajaran (RPP). (5)Menyusun instrumen pembelajaran sesuai dengan Rencana Pelaksanaan Pembelajaran (RPP). (6)Mengembangkan format evaluasi dan format observasi pembelajaran.

b. Pelaksanaan (Action): Kegiatan yang dilakukan dalam tahapan ini adalah pelaksanaan atau implementasi dari rencana pembelajaran yang telah disusun di dalam Silabus dan RPP yang menerapkan model pembelajarann kooperatif Giving Question anda Getting Answer.

c. Pengamatan: Pengamatan dilakukan terhadap pelaksanaan proses belajar, yaitu terhadap pelaksanaan tindakan, efek, hasil tindakan, sikap dan tingkah laku siswa. Semua yang diperlukan dicatat dengan menggunakan format observasi.

d. Refleksi: Kegiatan yang dilakukan pada tahap ini yaitu mengkaji secara menyeluruh tindakan yang telah dilakukan berdasarkan data yang telah terkumpul, kemudian dievaluasi guna menyempurnakan tindakan berikutnya untuk mengetahui hasil belajar siswa secaara individu dan klasikal.

\section{Teknik Pengumpulan Data \\ Observasi}

Pada observasi ini, penulis menggunakan lembar observasi aktivitas siswa dalam berkelompok dengan menganalisis tingkat keaktifan siswa saat proses belajar berlangsung. Adapun format observasi adalah sebagai berikut:

Tabel. 2 Observasi Aktivitas Siswa

\begin{tabular}{|c|c|c|c|c|c|c|c|c|c|c|c|}
\hline \multirow{2}{*}{ No. } & \multirow{2}{*}{$\begin{array}{c}\text { Nama } \\
\text { Siswa }\end{array}$} & \multicolumn{6}{|c|}{ Aspek yang dinilai } & \multicolumn{1}{c|}{$\begin{array}{c}\text { Jumla } \\
\text { h Skor }\end{array}$} & $\begin{array}{c}\text { K } \\
\text { et }\end{array}$ \\
\hline & & 1 & 2 & 3 & 4 & 5 & 6 & 7 & 8 & & \\
\hline 1 & & & & & & & & & & & \\
2 & & & & & & & & & & & \\
3 & & & & & & & & & & & \\
4 & & & & & & & & & & & \\
5 & & & & & & & & & & & \\
Dst & & & & & & & & & & & \\
\hline
\end{tabular}

Keterangan aspek aktivitas yang dinilai :

1. Visual Activities (memperhatikan guru) 
2. Oral Activities (bertanya dan mengeluarkan pendapat)

3. Listening Activities (mendengarkan pendapat siswa lain dan arahan guru)

4. Writing Activities (mencatat hasil diskusi)

5. Drawing Activities (membuat kolom, tabel)

6. Mental Activities (memberi tanggapan)

7. Motor Activities ( berdiskusi)

8. Emotional Activities (bersemangat, gembira, berani, dan minat)

Kriteria Skor:

1 = Tidak pernah melakukan

2 = Dilakukan namun jarang

3 = Sering dilakukan

4 = Sangat sering dilakukan

(Aqib,2008)

Kriteria Penilaian:

$23-32=$ Sangat Aktif $($ SA $)$

$23-27=\operatorname{Aktif}(\mathrm{A})$

$18-22=$ Cukup Aktif $(\mathrm{CA})$

$13-17=$ Kurang Aktif (KA)

$8-12=$ Tidak Aktif $(\mathrm{TA})$

(Aqib,2008)

\section{Tes hasil belajar}

Soal diberikan sebanyak tiga kali, yaitu pre test (sebelum pemberian tindakan), post test siklus I dan II. Dalam hal ini pre test dan post test berupa pilihan ganda yang diambil dari buku pegangan guru pada mata pelajaran mengelola pertemuan/rapat. Kemudian pada setiap akhir proses pembelajaran diberikan tugas untuk mengetahui kesiapan belajar siswa.

Untuk mengetahui persentase kemampuan siswa secara individual dari setiap siklusnya penulis menggunakan rumus:

$$
\mathrm{DS}=\frac{\text { Sy }}{\text { Smaks }} \times 100
$$

DS = Daya serap

Sy = skor yang diperoleh siswa

Smaks = skor maksimal

(Arikunto, 2008)

Dengan kriteria :

$0 \% \leq \mathrm{DS} \leq 75 \%$ siswa belum tuntas $75 \% \leq \mathrm{DS} \leq 100 \%$ siswa tuntas

Kriteria untuk penentuan tingkat penguasaan siswa terhadap materi pelajaran, dianalisis melalui pedoman berikut:

Tabel 3. Kategori Ketuntasan Penguasaan Materi

\begin{tabular}{|c|c|}
\hline $\begin{array}{c}\text { Persentase Penguasaan } \\
\text { Materi Pelajaran }\end{array}$ & $\begin{array}{c}\text { Kategori } \\
\text { Ketuntasan }\end{array}$ \\
\hline $85 \%-100 \%$ & Sangat Tuntas \\
\hline $75 \%-84 \%$ & Tuntas \\
\hline $55 \%-74 \%$ & Kurang Tuntas \\
\hline $0 \%-54 \%$ & Tidak Tuntas \\
\hline
\end{tabular}

Suatu kelas dikatakan berhasil (mencapai ketuntasan belajar) jika paling sedikit $85 \%$ data dari jumlah siswa dalam kelas tersebuttelah mencapai ketuntasan perorangan. Ketuntasan klasikal dapat dihitung dengan rumus sebagai berikut:

$\mathrm{D}=\frac{X}{N} \mathrm{X} 100 \%$

$\mathrm{D}=$ Presentase kelas yang tuntas belajar

$\mathrm{X}=$ Jumlah siswa yang telah tuntas belajar

$\mathrm{N}=$ Jumlah seluruh siswa

(Arikunto, 2008)

\section{HASIL DAN PEMBAHASAN \\ Hasil Penelitian \\ Deskripsi Hasil Penelitian}

Penelitian ini dilakukan di SMK Negeri 1 Sidikalang yang beralamat di Jl. Ahmad Yani No.136 Sidikalang tahun ajaran 2018/2019 dengan model pembelajaran kooperatif Giving Question and Getting Answer. Selama penerapan Model Pembelajaran kooperatif Giving Question and Getting Answer, sebagai pengamat adalah rekan peneliti sesama guru produktif .

Hasil Observasi Aktivitas Siswa: Pengamat melakukan pengamatan tentang aktivitas belajar siswa yang diaplikasikan melalui aktivitas siswa dalam peroses belajar mengajar. Observasi dilakukan setiap pertemuan dan diakumulasikan untuk setiap siklusnya. Berikut ini adalah skor rata-rata hasil observasi siswa oleh observer selama kegiatan belajar mengajar berlangsung. Hasil observasi aktivitas siswa dapat dilihat pada tabel berikut:

Tabel 4. Hasil Observasi Aktivitas Siswa

\begin{tabular}{|c|c|c|c|c|c|c|c|c|c|c|}
\hline Siklus & \multicolumn{2}{|c|}{ Tidak Aktif } & \multicolumn{3}{|c|}{ Kurang Aktif } & \multicolumn{3}{|c|}{ Cukup Aktif } & Aktif & Sangat Aktif \\
\hline & $\begin{array}{c}\text { Jlh } \\
\text { Siswa }\end{array}$ & $\%$ & $\begin{array}{c}\text { Jlh } \\
\text { siswa }\end{array}$ & $\%$ & $\begin{array}{c}\text { Jlh } \\
\text { siswa }\end{array}$ & $\%$ & $\begin{array}{c}\text { Jlh } \\
\text { siswa }\end{array}$ & $\%$ & $\begin{array}{c}\text { Jlh } \\
\text { siswa }\end{array}$ & $\%$ \\
\hline I & - & 0 & - & 0 & 30 & 83,33 & 6 & 16,66 & - & 0 \\
\hline II & - & 0 & - & 0 & 6 & 16,66 & 27 & 75 & 3 & 8,33 \\
\hline
\end{tabular}


$28-32=$ Sangat Baik $(\mathrm{AB})$

$23-27=$ baik $(\mathrm{B})$

$18-22=\operatorname{cukup}(\mathrm{C})$

$13-17=$ belum tuntas $(\mathrm{D})$

$8-12$ = tidak tuntas $(\mathrm{E})$

Tabel. 4 digambar dalam bentuk diagram untuk melihat peningkatan hasil observasi aktivitas belajar siswa pada setiap siklus sebagai berikut :

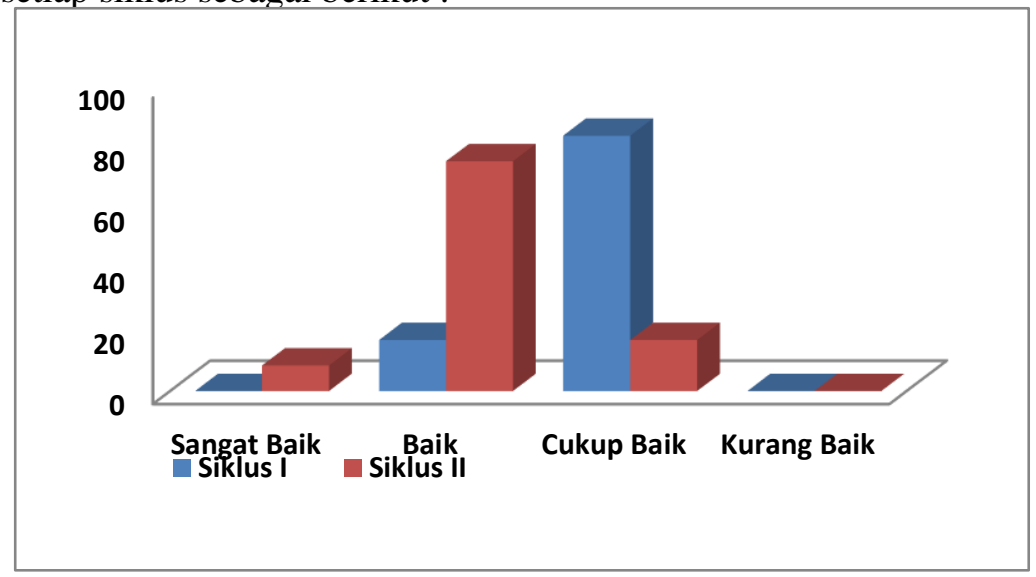

Gambar 2. Grafik Observasi Aktivitas Siswa

\section{Test Hasil Belajar}

Hasil pretest berfungsi untuk melihat kemampuan awal siswa sedangkan postest untuk melihat kemampuan akhir siswa setelah diterapkannya model pembelajaran kooperatif
Giving Question and Getting Answer pada standar kompetensi mengelola pertemuan/rapat. Adapun hasil perolehan nilai dan persentase siswa pada saat pretest dan postest adalah sebagai berikut:

Tabel. 5 Hasil Belajar Siswa

\begin{tabular}{|c|l|c|c|c|c|c|c|}
\hline \multirow{2}{*}{ No } & \multirow{2}{*}{ Ket } & \multicolumn{3}{|c|}{ Jumlah Siswa } & \multicolumn{3}{c|}{ Persentase } \\
\cline { 3 - 8 } & & Pre test & Pos test I & Postest II & Pre test & Pos test I & Pos test II \\
\hline 1 & Tuntas & 5 & 13 & 32 & 13,88 & 36,11 & 88,88 \\
\hline 2 & Tidak Tuntas & 31 & 23 & 4 & 86,11 & 63,88 & 11.11 \\
\hline
\end{tabular}

Dari tabel di atas dapat digambarkan hasil belajar pretest dan postest yang diperoleh siswa pada diagram berikut:

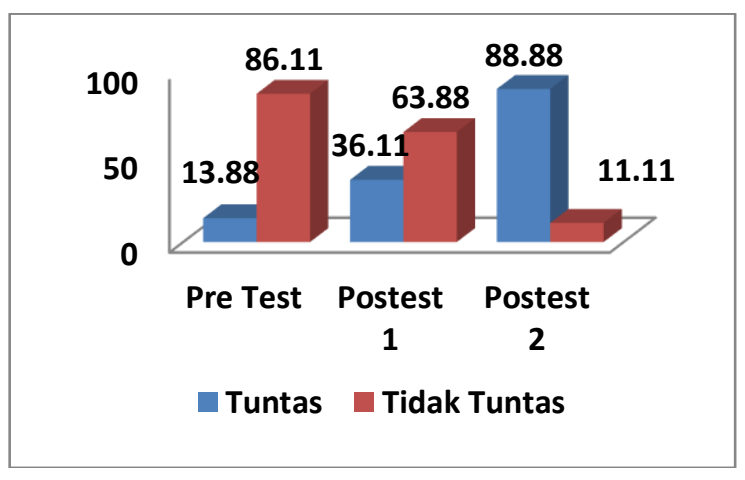

Gambar 3. Diagram Hasil Belajar

\section{Pembahasan Hasil Penelitian}

Pada awal kegiatan penelitian diberikan pretest berupa soal pilihan berganda sebanyak 10 soal untuk mengetahui sejauh mana tingkat pemahaman siswa terhadap materi yang akan dipelajari, dan setiap akhir pembelajaran pada siklus diberi tes individu. Apabila hasil belajar siswa di bawah kriteria ketuntasan minimalnya yaitu minimal 75 maka siswa belum tuntas belajar, dan apabila 85\% dari jumlah siswa belum mencapai nilai 75 maka ketuntasan secara klasikal belum terpenuhi sehingga akan dilanjutkan ke siklus berikutnya.

\section{Siklus I}

\section{Perencanaan (Planning)}

Pada tahap ini, guru membuat rencana pelaksanaan pembelajaran sesuai dengan model pembelajaran kooperatif Giving Question and Getting Answer, membahas tes yang akan diberikan kepada siswa dan menyusun lembar observasi untuk mengukur aktivitas siswa. 
2. Pelaksanaan (Action)

Pada tahap ini, guru menerapkan model pembelajaran kooperatif Giving Question and Getting Answer yang sudah dirancang dalam rencana pelaksanaan pembelajaran. Pada tahap siklus I pertemuan pertama diawali dengan test awal (pretes) yang dilakukan sebelum materi pokok diajarkan yaitu Notulen Rapat. Hal ini dilakukan untuk mengetahui sejauh mana pengetahuan awal siswa pada awal materi awal tersebut. Dari tabel. 4 diperoleh hasil persentase nilai pretes siswa yang tuntas adalah 13,88\% dengan rata-rata nilai siswa 60,83. Pada siklus I siswa yang nilainya telah mencapai standart kriteria ketuntasan minimal belajar yang diterapkan sekolah masih $36,11 \%$.

Adapun postes dilakukan diakhir pertemuan yaitu untuk mengetahui tingkat penguasaan siswa terdahap materi yang diberikan. Skor rata-rata yang diperoleh siswa rata-rata 70,27 dimana nilai ini meningkat dari hasil pretest yang dilakukan diawal pertemuan yang hanya rata-rata 60,83 .

3. Pengamatan (Observation)

Pengamat (observer) mengamati aktivitas siswa selama pembelajaran berlangsung. Hasil observasi aktivitas siswa juga tergolong baik meskipun ada beberapa aspek yang masih di bawah standar yaitu terdapat 30 orang $(83,33 \%)$ untuk kriteria cukup aktif, , dan hanya 6 orang $(16,66 \%)$ siswa untuk kriteria kriteria aktif .

4. Refleksi (Reflection)

Hasil analisis data diperoleh dari nilai pre test dan nilai post test pada siklus I dan lembar observasi. Berdasarkan analisis data tersebut diketahui bahwa antara pre test dan post test siklus I terjadi perubahan. Pada saat pre test jumlah siswa yang tuntas belajar adalah 5 orang $(13,88 \%)$, sedangkan pada post test jumlah siswa yang tuntas belajar menjadi 13 orang $(36,11 \%)$. Dengan ratarata 70,27 . Perolehan ini belum memenuhi kriteria ketuntasan klasikal yaitu $85 \%$ siswa harus memperoleh nilai $\geq 75$, sehingga perlu dilanjutkan ke siklus selanjutnya.

Hasil observasi selama pembelajaran belum menunjukkan keaktifan siswa dalam kelompok. Hal ini terlihat dari individu siswa yang masih sulit jika diminta untuk mengajukan pertanyaan, memberi tanggapan, dan dalam melakukan kegiatan belum dapat bekerja secara berkelompok. Masalah-masalah yang ditemukan pada siklus I ini menjadi bahan masukan bagi peneliti untuk perbaikan dalam merancang tahapan pada siklus selanjutnya.

\section{Siklus II}

1. Perencanaan (Planning)

Dalam siklus II dirancang untuk memperbaiki kelemahan-kelemahan yang ditemukan pada siklus I.

2. Pelaksanaan (Action)

Pada siklus II ini kegiatan belajar mengajar berlangsung sesuai dengan rencana pelaksanaan pembelajaran. Postest pada siklus II dilakukan pada pertemuan keempat, postest dilakukan untuk mengetahui kemampuan akhir siswa dan peningkatan kemapuan siswa setalah diterapkan metode pembelajara kooperatif Giving Question and Getting Answer. Pada siklus II diperoleh peningkatan hasil rata-rata yang diperoleh dari siklus I yaitu dari 70,27 menjadi 81,38 dan dari ketuntasan hasil belajar 36,11\% (13 orang) yang telah mencapai standart kriteria ketuntasan minimal meningkat menjadi $88,88 \%$. Siswa telah mencapai kriteria ketuntasan minimal $75 \%$ maka proses belajar mengajar pada mata pelajaran mengelola pertemuan/rapat dikatakan berhasil.

3. Pengamatan (Observation)

Pada kegiatan belajar mengajar aktivitas siswa lebih meningkat dan siswa lebih terbuka mengemukakan masalah yang dihadapi dan yang kurang dipahami selama kegiatan belajar mengajar berlangsung. Pada siklus II, data hasil observasi aktivitas siswa menunjukkan 6 orang $(16,66 \%)$ untuk kriteria cukup aktif, 27 orang $(75 \%)$ siswa untuk kriteria aktif dan 3 orang $(8,33 \%)$ siswa untuk kriteria sangat aktif.

4. Refleksi (Reflection)

Diperoleh peningkatan rata-rata hasil belajar siswa dari siklus I ke siklus II sebesar 11,11 dan juga sekaligus menandakan bahwa tidak perlu lagi dilaksanakan siklus berikutnya karena jumlah siswa yang tuntas belajar sebesar $88,88 \%$. Hal ini menunjukkan bahwa siklus II sudah mencapai kriteria ketuntasan secara klasikal $85 \%$, siswa harus mencapai $\geq 75$. Dengan keberhasilan yang dicapai pada siklus II, membuktikan bahwa dengan penerapan metode pembelajaran kooperatif Giving Question and Getting Answer dapat meningkatkan aktivitas dan hasil belajar pada materi mengelola 
pertemuan/rapat sehingga tidak perlu dilanjutkan pada siklus berikutnya.

Hal ini di dukung oleh Amalia Chasanah, dkk (2012:30) mengatakan bahwa strategi pembelajaran Giving Question and Getting Answer (GQGA) merupakan salah satu strategi pembelajaran Active Learning yang mengimplementasikan dari strategi pembelajaran konstruktivistik yang menempatkan siswa sebagai subjek dalam pembelajaran yang dikembangkan untuk melatih siswa memiliki kemampuan dan keterampilan bertanya dan menjawab karena pada dasarnya model tersebut merupakan modifikasi dari tanya jawab. Dengan penggunaan model pembelajaran Giving Question and Getting Answer (GQGA) siswa kemampuannya meningkat, aktivitas belajarnya meningkat dan tentu hasil belajarnya meningkat.

\section{PENUTUP}

Berdasarkan pembahasan hasil penelitian, dapat dikesimpulan sebagai berikut: (1) Penerapan model pembelajaran kooperatif Giving Question and Getting Answer dapat meningkatkan aktivitas belajar siswa. Hal ini terlihat pada hasil obsevasi siklus I diperoleh data bahwa terdapat 30 orang $(83,33 \%)$ siswa untuk kriteria cukup aktif, dan 6 orang $(16,66 \%)$ siswa yang aktif. Sementara pada siklus II peningkatan data hasil obsevasi aktivitas siswa menunjukkan 6 orang $(16,66 \%)$ siswa untuk kriteria cukup aktif, 27 orang $(75 \%)$ siswa untuk kriteria aktif, dan 3 orang $(8,33 \%)$ siswa untuk kriteria sangat aktif. (2) Model pembelajaran kooperatif Giving Question and Getting Answer juga terbukti dapat meningkatkan hasil belajar siswa. Hal ini terlihat pada siklus I diperoleh nilai rata-rata 70,27 dan persentase ketuntasan belajar siswa sebesar $36,11 \%$ selanjutnya pada siklus II diperoleh nilai rata-rata 81,38 dan persentase ketuntasan siswa sebesar $88,88 \%$ dari jumlah siswa yang telah mencapai standar kriteria ketuntasan minimal.

\section{DAFTAR PUSTAKA}

Arikunto, S. (2008). Penelitian Tindakan Kelas. Jakarta: PT. Bumi Aksara

Arikunto, dkk. (2009). Prosedur Penelitian. Jakarta: Bumi Aksara.

Asmawati, Andi, dkk. (2011). Pengaruh Penerapan Model Pembelajaran Kooperatif Tipe Giving Question and
Getting Answer Pada Konsep Sistem Gerak Terhadap Hasil Belajar Siswa SMAN 4 Bantimurung. Jurnal Pendidikan Biologi FMIPA. 12 (2) ISSN 1411-4720. Universitas Negeri Makassar. Aqib, Z. (2008). Penelitian Tindakan Kelas. Bandung: Yrama Widya.

Chasanah, Amalia, dkk. (2012). Pengaruh Penerapan Model Pembelajaran Giving Questionand Getting Answer Terhadap Hasil Belajar Siswa Kelas SMAN Banyudono T.A 2011/2012. Jurnal Pendidikan Biologi FKIP. 4 (3) Universitas Sebelas Maret.

Djamarah, Syaiful Bahri dan Zain, Aswan. (2010). Strategi Belajar Mengajar. Jakarta: Rineka Cipta.

Elly, Nor, (2014). Pengaruh Pembelajaran Kooperatif STAD Terhadap Hasil Belajar Siswa Materi Elastisitas Kelas XI SMAN Gedangan. Jurnal Inovasi Pendidikan Fisika. 3 (1) ISSN 2302-4496. Universitas Negeri Surabaya.

Hartati, Tri, dkk. (2012). Penerapan Model Pembelajaran Bermain Peran (Role Playing) dalam meningkatkan Hasil Belajar Ekonomi. Jurnal Pendidikan Ekonomi FE. 1(1) ISSN: 2252-6544. Universitas Negeri Semarang.

Isjoni. (2011). Cooperative Learning Mengembangkan Kemampuan Belajar Kelompok. Bandung: Alfabeta.

Kunandar. (2008). Langkah Mudah Penelitian Tindakan Kelas Sebagai Pengembangan Profesi Guru. Jakarta: PT Rajagrafindo Persada.

Muktiani, Endah. (2012). Penerapan Metode Pembelajaran Giving Question and Getting Answer Untuk Meningkatkan Keaktifan dan Hasil Belajar Akuntansi Pada Siswa Kelas XI IPS 2 SMA Negeri 1 Kartasura Tahun Ajaran 2011/2012. Skripsi. Semarang: UNNES.

Nursalim. (2007). Psikologi Pendidikan. Surabaya. Unesa University Press.

Sagala, Syaiful. (2012). Konsep dan Makna Pembelajaran. Jakarta: Rineka Cipta.

Susanti, Nelya Eka. (2012). Penerapan Model Pembelajaran Kooperatif Giving Question And Getting Answers Untuk Meningkatkan Aktivitas dan Hasil Belajar IPS Geografi Siswa Kelas VII-H (Kelas Olahraga) Semester 2 di SMP RSBI Negeri 1 Batu. Skripsi. Jurusan Pendidikan Geografi FIS Universitas 
Negeri Malang.

Trianto. (2010). Mendesain Model

Pembelajaran Inovatif-Progresif:

Konsep, Landasan, dan

Implementasinya Pada Kurikulum

Tingkat Satuan Pendidikan (KTSP).

Jakarta: Kencana Prenada Media Group.

Usman, Moh. Uzer. (2002). Menjadi Guru

Profesional. Bandung: PT Remaja Rosda Karya.

Veranita, Ayu. (2010). Penerapan Strategi Pembelajaran Aktif Tipe Giving Questions and Getting Answer Untuk Meningkatkan Aktivitas Siswa Dalam Pembelajaran Matematika di Kelas VII Semester II SMP Negeri 2 Kartasura Tahun Ajaran 2009/2010. Skripsi. Semarang: UNNES. 